\title{
PENERAPAN CUCI TANGAN PAKAI SABUN DI SDN II KOTA KARANG BANDAR LAMPUNG
}

\author{
Sri Murwaningsih \\ Dosen Jurusan Teknik Gigi Poltekkes Tanjungkarang \\ Email: naming.jtg@gmail.com
}

\begin{abstract}
Application of Hand Washing with Soap in SDN II Kota Karang Bandar Lampung. Washing Hand with Soap (CTPS) is one of the measures considered effective to prevent the transmission of diseases mediated by hand. The study says that the CTPS can reduce the death rate caused by diarrhea. Behavior Washing Hand is one indicator Behavior Clean and Healthy Lifestyle (PHBS) in Schools. Children at school as the future generation with age are highly susceptible to a variety of disease transmission so it should be emphasized to familiarize Washing Hand with Soap. SDN II Kota Karang Bandar Lampung data of 20 fifth grade students of SDN II Kota Karang only 4\% who do washing hand with soap and water before eating, 96\% washing hands not with soap and results interviews with nearly all students do not know the importance of getting used washing hand with soap and running water. The research objective was to determine thefactors related to the implementation of washing hand in SDN II Kota Karang Bandar Lampung. Methods using a cross sectional study, with 80 students as a sample. Results a good knowledge of respondents with $65 \%$ an attitude to support $68.8 \%$, the availability of $55 \%$, role of teachers and support $66.2 \%$ of respondents apply washing hand $71.2 \%$. There was no relationship between knowledge of handwashing. There is a significant relationship between attitude, availability of facilities, the role of teachers to washing hand, with $\mathrm{OR}=4.87$, the role of teachers $\mathrm{OR}=3.99$ and Means with $\mathrm{OR}=3.21$.
\end{abstract}

Keywords: Washing Hand, Students, School, Children

\begin{abstract}
Abstrak: Penerapan Cuci Tangan Pakai Sabun di SDN II Kota Karang Bandar Lampung. Cuci Tangan Pakai Sabun (CTPS) adalah salah satu tindakan yang dinilai efektif untuk mencegah penularan berbagai penyakit yang diperantarai tangan. Hasil penelitian menyebutkan bahwa CTPS dapat menekan angka kematian yang disebabkan oleh diare. Perilaku Cuci Tangan Pakai Sabun adalah salah satu indikator Perilaku Hidup Bersih dan Sehat (PHBS) di Sekolah. Anak Sekolah sebagai generasi penerus bangsa dengan usia yang sangat rentan terhadap berbagai penularan penyakit sangat perlu ditekankan untuk membiasakan Cuci Tangan Pakai Sabun. Di SDN II Kota Karang Bandar Lampung diperoleh data dari 20 orang siswa kelas V SDN II Kota Karang hanya 4\% yang melakukan cucitangan dengan sabun dan air bersih sebelum makan, 96\% mencuci tangan tidak dengan sabun dan hasil wawancara dengan siswa hampir semua tidak mengetahui pentingnya membiasakan perilaku cuci tangan dengan sabun dan air mengalir. Tujuan penelitian untuk mengetahui faktor-faktor yang berhubungan dengan penerapan Cuci Tangan Pakai Sabun di SDN II Kota Karang Bandar Lampung. Metode Penelitian Cross Sectional Study, dengan 80 orang siswa sebagai sampel.Hasil, responden dengan pengetahuan baik $65 \%$, sikap mendukung $68,8 \%$, ketersediaan sarana $55 \%$, guru mendukung sebanyak $66,2 \%$ dan responden menerapkan perilaku cuci tangan 71,2\%. Tidak terdapat hubungan pengetahuan terhadap perilaku cuci tangan, terdapat hubungan signifikan antara sikap, ketersediaan sarana, peran guru terhadap perilaku cuci tangan, nilai $\mathrm{OR}=4,87$, peran guru nilai $\mathrm{OR}=3,99$, dan sarana nilai $\mathrm{OR}=3,21$.
\end{abstract}

Kata Kunci: Cuci Tangan, Siswa, Anak, Sekolah

Masalah kesehatan yang timbul pada anak sekolah biasanya berkaitan dengan kebersihan diri (personal hygiene) diantaranya seperti: tidak menggosok gigi secara baik dan benar, tidak memotong kuku secara rutin satu minggu sekali dan tidak membiasakan diri mencuci tangan dengan sabun dan air mengalir. Kebiasaan tidak mencuci tangan dengan sabun dan air mengalir dapat menyebabkan penyakit diantaranya diare, penyakit kulit, Infeksi Saluran Napas Atas (ISPA) dan kecacingan.

Kuman penyakit baik berbentuk virus atau bakteri tidak terlihat secara kasat mata sehingga sering diabaikan dan tanpa disadari tangan seringkali menjadi agent yang membawa kuman dan menyebabkan patogen berpindah dari satu orang ke orang lain, baik dengan kontak langsung ataupun tidak langsung (menggunakan permukaan-permukaan lain seperti handuk, 
gelas). Dengan demikian tangan adalah salah satu penghantar utama masuknya kuman penyakit ke tubuh manusia. Tangan merupakan bagian tubuh yang lembab, paling sering berkontak dengan kuman yang menyebabkan penyakit dan menyebarnya (Kamaruddin, 2009).

Hampir semua orang mengerti pentingnya cuci tangan dengan sabun, namun tidak membiasakan diri melakukannya dengan benar pada saat yang penting. Mencuci tangan pakai sabun dilakukan pada 5 waktu penting: sebelum makan, sesudah buang air besar, sebelum memegang bayi, sesudah menceboki anak, dan sebelum menyiapkan makanan. Demikian pula pada penerapan Perilaku Hidup Bersih dan Sehat di tatanan Sekolah Dasar kususnya indikator Cuci Tangan Pakai Sabun belum di terapkan secara menyeluruh.

Langkah-langkah Cuci Tangan yang benar ada enam langkah yaitu membasahi tangan dan menggosok kedua telapak tangan, punggung tangan dan sela-sela jari, punggung jari, menggosok ibu jari dan kuku kemudian bilas air bersih (Puspromkes RI, 2010). Penelitian di Angolela (Basona Werena) Ethiopia menunjukan bahwa hanya $52 \%$ siswa yang mempunyai pengetahuan tentang kebersihan perorangan dengan baik (Vivas dkk., 2010) dan hanya 33,6\% siswa SD di Bogota yang melakukan CTPS (Lopez-Quintero dkk.,2009).

Riset Kesehatan Dasar (Riskesdas) 2007, perilaku cuci tangan masyarakat Indonesia masih rendah, dan anak usia sekolah dasar, baru 17\% melakukan Cuci Tangan Pakai sabun dan air bersih. Riskesdas 2013 proporsi pada umur $\geq 10$ tahun yang melakukan cuci tangan dengan benar 46,7\%. Direktorat Jenderal Pengendalian Penyakit dan Penyehatan Lingkungan Kemenkes RI (2013) menyebutkan hanya 18,5\% masyarakat Indonesia yang mencuci tangan dengan sabun di lima waktu penting. Basic Human Services (BHS) di Indonesia tahun 2006 menemukan baru $12 \%$ yang melakukan CTPS setelah buang air besar, $14 \%$ sebelum makan, 9\% setelah menceboki anak dan $6 \%$ sebelum menyiapkan makanan (Kemenkes,2010a : Kemenkes 2012a).

Tujuan penelitian, mengetahui Faktorfaktor yang berhubungan dengan Penerapan Cuci Tangan Pakai Sabun dan Air Bersih mengalir di SD Negeri II Kota Karang Bandar Lampung pada Tahun 2015"

\section{METODE PENELITIAN}

Penelitian ini menggunakan desain desain Cross Sectional, sebagai populasi adalah seluruh siswa kelas VI Sekolah Dasar Negeri II Kota Karang yang berjumlah 80 orang. Sampel penelitian ini adalah total populasi. Sesuai pendapat Sugiono, 2007 pengambilan total populasi dikarenakan populasi kurang dari 100 .

Pengambilan data menggunakan instrumen kuesioner dan check-list, yang sebelumnya telah dilakukan uji validitas yaitu uji korelasi Pearson Product Moment dan didapatkan $\mathrm{r}$ hitung lebih besar dari $\mathrm{r}$ tabel, ( $\mathrm{r}$ tabel 0,361). Soegiono (2007), Uji validitas pada 30 responden, nilai $r$ tabel ditentukan berdasarkan rumus yaitu df (n$2), d f=30-2=28$ sehingga pada taraf signifikan 0,05 di dapat angka 0,361 dengan demikian kuesioner penelitian ini dikatakan valid. Pengambilan data dengan wawancara dan observasi.

Analisis untuk mengetahui distribusi frekuensi dengan analisis univariat dan untuk mengetahui hubungan masing-masing variabel bebas terhadap variabel terikat menggunakan analisis bivariat chi square.

\section{HASIL}

\section{Pengetahuan}

Tabel 1. Distribusi Frekuensi Pengetahuan Responden tentang Penerapan Cuci Tangan Pakai Sabun dan Air Mengalir

\begin{tabular}{|c|c|c|}
\hline $\begin{array}{l}\text { Pengetahuan Tentang cuci } \\
\text { tangan }\end{array}$ & f & $(\%)$ \\
\hline Baik & 52 & 65 \\
\hline Kurang & 28 & 35 \\
\hline Total & 80 & 100 \\
\hline
\end{tabular}

Berdasarkan tabel 1, diketahui bahwa responden yang memiliki pengetahuan baik tentang cuci tangan lebih besar $(65 \%)$ daripada yang pengetahuan kurang (35\%).

\section{Sikap}

Tabel 2. Distribusi Frekuensi Sikap Responden tentang Penerapan Cuci Tangan Pakai Sabun dan Air Mengalir

\begin{tabular}{lcc}
\hline \multicolumn{1}{c}{ Sikap } & f & (\%) \\
\hline Mendukung & 55 & 68.8 \\
Tidak Mendukung & 25 & 31.2 \\
\hline \multicolumn{1}{r}{ Total } & 80 & 100 \\
\hline
\end{tabular}

Dengan memperhatikan tabel 2, diketahui bahwa responden yang memiliki sikap 
mendukung cuci tangan menggunakan sabun $68,8 \%$ dan yang tidak mendukung (35\%).

\section{Sarana}

Tabel 3. Distribusi Frekuensi Ketersediaan Sarana Cuci Tangan Pakai Sabun dan Air Mengalir

\begin{tabular}{|c|c|c|}
\hline Sarana cuci tangan & $\mathrm{f}$ & $(\%)$ \\
\hline Tersedia & 44 & 55 \\
\hline Tidak Tersedia & 36 & 45 \\
\hline Total & 80 & 100 \\
\hline
\end{tabular}

Berdasarkan tabel 3, diketahui bahwa responden yang memiliki sarana cuci tangan lebih besar $(55 \%)$ dibandingkan dengan responden yang tidak tersedia sarana cuci tangan $(45 \%)$.

\section{Peran Guru}

Tabel 4. Distribusi Frekuensi Peran Guru terhadap Cuci Tangan Pakai Sabun dan Air Mengalir

\begin{tabular}{lcc}
\hline \multicolumn{1}{c}{ Peran guru } & $\mathrm{f}$ & $\mathbf{( \% )}$ \\
\hline Berperan & 53 & 66.2 \\
Tidak Berperan & 27 & 33.8 \\
\hline \multicolumn{1}{c}{ Total } & 80 & 100 \\
\hline
\end{tabular}

Berdasarkan tabel 4, terlihat bahwa prosentase responden mendapat peran guru lebh banyak (66,2 \%), dibandingkan dengan responden yang tidak mendapat peran guru $(33,8 \%)$.

\section{Perilaku Mencuci Tangan Pakai Sabun}

Tabel 5. Distribusi Frekuensi Perilaku Cuci Tangan Pakai Sabun dan Air Mengalir

\begin{tabular}{lcc}
\hline \multicolumn{1}{c}{ Perilaku CTPS } & $\mathrm{f}$ & $\mathbf{( \% )}$ \\
\hline Menerapkan & 57 & 71.2 \\
Tidak Menerapkan & 23 & 28.8 \\
\hline \multicolumn{1}{c}{ Total } & 80 & 100 \\
\hline
\end{tabular}

Memperhatikan tabel 5, diketahui bahwa responden yang menerapkan perilaku CTPS lebih banyak (71,2\%), sedangkan yang tidak menerapkan CTPS $(28,8 \%)$.

6. Hubungan sikap responden dengan penerapan perilaku cuci tangan pakai sabun dan air mengalir
Responden yang menerapkan perilaku Cuci Tangan Pakai Sabun lebih banyak $(81,8 \%)$ merupakan responden yang memiliki sikap mendukung perilaku Cuci Tangan Pakai Sabun. Sedangkan responden yang tidak menerapkan perilaku Cuci Tangan Pakai Sabun lebih banyak (52\%) merupakan responden dengan sikap tidak mendukung penerapan perilaku Cuci Tangan Pakai Sabun.

Tabel 6. Hasil Analisis Hubungan Sikap terhadap Penerapan Perilaku Cuci Tangan Pakai Sabun

\begin{tabular}{|c|c|c|c|c|c|c|}
\hline \multirow{3}{*}{ Sikap } & \multicolumn{4}{|c|}{ Cuci tangan Pakai Sabun } & \multirow{2}{*}{\multicolumn{2}{|c|}{ Total }} \\
\hline & \multicolumn{2}{|c|}{ Menerapkan } & \multicolumn{2}{|c|}{$\begin{array}{c}\text { Tidak } \\
\text { Menerapkan }\end{array}$} & & \\
\hline & $\mathrm{f}$ & $\%$ & $\mathrm{f}$ & $\%$ & $\mathrm{f}$ & $\%$ \\
\hline Mendukung & 45 & 81,8 & 10 & 18,2 & 55 & 100 \\
\hline $\begin{array}{l}\text { Tidak } \\
\text { mendukung }\end{array}$ & 12 & 48,0 & 13 & 52,0 & 25 & 100 \\
\hline Total & 57 & 71,25 & 23 & 28,75 & 80 & 100 \\
\hline
\end{tabular}

Hasil p value 0,005 dengan OR 4,87 pada tingkat kepercayaan $95 \%$

Uji statistic menunjukkan $p$ value 0,005 nilai tersebut lebih kecil dari alpha $(0,05)$ sehingga hipotesis nol di tolak, dengan demikian berarti ada hubungan yang signifikan antara sikap dengan penerapan perilaku Cuci Tangan Pakai Sabun di SD II Kota Karang. Hasil odd ratio adalah 4,87 artinya responden dengan sikap mendukung memiliki peluang untuk menerapkan periaku Cuci Tangan Pakai Sabun di Sekolah 4,87 kali lebih tinggi disbanding responden dengan sikap tidak mendukung.

7. Hubungan Ketersediaan Sarana Cuci Tangan dengan Penerapan Perilaku Cuci Tangan Pakai Sabun dan Air Mengalir

Tabel 7. Hasil Analisis Hubungan

\begin{tabular}{|c|c|c|c|c|c|c|}
\hline \multirow{4}{*}{ Sarana } & \multicolumn{6}{|c|}{$\begin{array}{l}\text { Ketersediaan Sarana terhadap } \\
\text { Penerapan Perilaku Cuci Tangan } \\
\text { Pakai Sabun }\end{array}$} \\
\hline & \multicolumn{4}{|c|}{ Cuci tangan Pakai Sabun } & \multirow{2}{*}{\multicolumn{2}{|c|}{ Total }} \\
\hline & \multicolumn{2}{|c|}{ Menerapkan } & \multicolumn{2}{|c|}{$\begin{array}{c}\text { Tidak } \\
\text { Menerapkan }\end{array}$} & & \\
\hline & $\mathrm{f}$ & $\%$ & $\mathrm{f}$ & $\%$ & $\mathrm{f}$ & $\%$ \\
\hline Tersedia & 36 & 81,8 & 8 & 18,2 & 44 & 100 \\
\hline $\begin{array}{l}\text { Tidak } \\
\text { Tersedia }\end{array}$ & 21 & 58,3 & 15 & 41,7 & 36 & 100 \\
\hline Total & 57 & 71,25 & 23 & 28,75 & 80 & 100 \\
\hline
\end{tabular}

Hasil $p$ value 0,039 dengan OR 3,21 pada tingkat kepercayaan $95 \%$ 
Dari tabel di atas diketahui responden yang menerapkan perilaku Cuci Tangan Pakai Sabun lebih banyak $(81,8 \%)$ merupakan responden yang mempunyai pendapat sarana tersedia. Sedangkan responden yang tidak menerapkan perilaku Cuci Tangan Pakai Sabun lebih banyak $(41,7 \%)$ merupakan responden yang mempunyai pendapat tidak tersedia sarana.

Hasil Uji Statistik menunjukkan $p$ value 0,039 ; lebih kecil dari alpha $(0,05)$ sehingga hipotesis nol ditolak, berarti terdapat hubungan signifikan antara ketersdiaan sarana dengan perilaku Cuci Tangan Pakai Sabun di SD II Kota Karang. Hasil odd ratio 3,21, artinya responden dengan pendapat sarana tersedia memiliki peluang untuk menerapkan perilaku Cuci Tangan Pakai Sabun 3,21 lebih tinggi dibandingkan responden dengan pendapat tidak tersedia sarana.

\section{Hubungan Peran Guru dengan Penerapan Perilaku Cuci Tangan Pakai Sabun dan Air Mengalir}

Tabel 8. Hasil Analisis Hubungan Peran Guru terhadap Penerapan Perilaku Cuci Tangan Pakai Sabun

\begin{tabular}{lcccccc}
\hline \multirow{2}{*}{$\begin{array}{c}\text { Peran } \\
\text { Guru }\end{array}$} & \multicolumn{4}{c}{ Cuci tangan Pakai Sabun } & \multirow{2}{*}{ Total } \\
\cline { 2 - 5 } & Menerapkan & \multicolumn{2}{c}{$\begin{array}{c}\text { Tidak } \\
\text { Menerapkan }\end{array}$} & & \\
\cline { 2 - 6 } & $\mathrm{f}$ & $\%$ & $\mathrm{f}$ & $\%$ & $\mathrm{~F}$ & $\%$ \\
\hline Berperan & 43 & 81,1 & 10 & 18,9 & 53 & 100 \\
$\begin{array}{l}\text { Tidak } \\
\text { Berperan }\end{array}$ & 14 & 51,9 & 13 & 48,1 & 27 & 100 \\
\hline Total & 57 & 71,3 & 23 & 28,75 & 80 & 100 \\
\hline
\end{tabular}

Hasil $p$ value 0,013 dengan OR 3,99 pada tingkat kepercayaan $95 \%$

Tabel di atas menunjukkan responden yang menerapkan perilaku Cuci Tangan Pakai Sabun lebih banyak $(81,1 \%)$ merupakan responden mendapat peran guru dalam penerapan perilaku Cuci Tangan Pakai Sabun di Sekolah. Sedangkan responden yang tidak menerapkan perilaku Cuci Tangan Pakai Sabun lebih banyak $(48,1 \%)$ merupakan responden tidak mendapat peran guru dalam penerapan perilaku Cuci Tangan Pakai Sabun di Sekolah.

Hasil Uji statistik menunjukkan $p$ value 0,013 nilai tersebut lebih kecil dari alpha $(0,05)$ sehingga hipotesis nol ditolak. Artinya terdapat hubungan yang signifikan antara peran guru dengan penerapan perilaku Cuci Tangan Pakai Sabun di SD II Kota Karang. Odd rasio adalah 3,99 yang artinya responden yang mendapat peran guru memiliki peluang untuk menerapkan perilaku Cuci Tangan Pakai Sabun 3,99 kali lebih tinggi disbanding responden yang tidak mendapat peran guru.

\section{PEMBAHASAN}

\section{Pengetahuan penerapan Cuci Tangan Pakai Sabun dan Air Mengalir}

Hasil analisis menggambarkan distribusi siswa kelas VI SDN II Kota Karang dengan pengetahuan cuci tangan baik adalah 52 orang (65\%) sedangkan siswa kelas VI dengan pengetahuan kurang baik adalah 28 orang (35\%). Dengan demikian hasil analisa univariat pada faktor pengetahuan cuci tangan menunjukan prosentase terbanyak adalah pada siswa berpengetahuan baik.

Berbeda dengan hasil penelitian Monica dkk, dalam jurnal Stikes borromeus tentang Faktor-faktor yang berhubungan dengan perilaku mencuci tangan pada anak Sekolah Dasar Negeri 03 Kertajaya menunjukkan hasil $p$ value faktor pengetahuan 0,995 yang berarti tidak ada hubungan antara pengetahuan dengan perilaku mencuci tangan pada anak SDN 03 Kertajaya.

Pengetahuan merupakan domain yang sangat penting dalam membentuk tindakan seseorang. (Notoadmodjo, 2003 :121). Pengetahuan merupakan salah satu modal utama yang dapat mendorong seseorang untuk melakukan suatu tindakan berdasarkan pengalaman apa yang telah dilihat dan di dengar. Sehingga pengetahuan menjadi salah satu dasar untuk terjadinya perilaku.

Penelitian Zuraidah (2013) di Kabupaten Lubuk Linggau tentang hubungan pengetahuan, Sikap dan Perilaku Cuci Tangan Pakai Sabun yang benar pada siswa kelas V SDIT AN-NIDA "menunjukkan adanya hubungan signifikan antara pengetahuan dengan perilaku mencuci tangan dengan $p$ value $=0,029$.

Dari hasil wawancara dengan responden, sebelumnya sudah ada beberapa penyuluhan tentang perilaku mencuci tangan dari beberapa instansi perguruan kesehatan yang mengadakan kegiatan penyuluhan tentang perilaku mencuci tangan di sekolah.

Selaras dengan penelitian Ratna Wati (2011) di Surakarta tentang Pengaruh Pemberian Penyuluhan PHBS tentang mencuci tangan terhadap Pengetahuan dan Sikap mencuci tangan pada siswa kelas V SDN Bulukantil menunjukkan hubungan yang signifikan dengan $p$ value pengetahuan $=0,000$ 


\section{Sikap terhadap Penerapan Cuci Tangan Pakai Sabun dan Air Mengalir}

Prosentase lebih banyak pada responden dengan Sikap mendukung yaitu $68,8 \%$ dan sisanya adalah responden dengan sikap tidak mendukung yaitu $35 \%$.

Hasil analisis menggambarkan distribusi siswa kelas VI SD II Kota Karang dengan sikap mendukung terhadap perilaku cuci tangan sebanyak 55 orang $(68,8 \%)$, sedangkan siswa dengan sikap tidak mendukung sebanyak 25 orang $(31,2 \%)$. Dengan demikian hasil penelitian menggambarkan prosentase terbanyak adalah pada siswa dengan sikap mendukung.

Sikap adalah keteraturan tertentu dalam hal (afeksi), pemikiran (kognisi), dan predisposisi tindakan (konasi) seseorang terhadap suatu aspek di lingkungan sekitarnya.

Sikap adalah kesiapan atau kecenderungan seseorang untuk bertindak berkenaan dengan objek tertentu. Sikap dapat mempengaruhi seseorang untuk memilih sesuatu yang dianggap benar, disaat ia dihadapkan di pilihan yang benar dan salah, karena sikap merupakan emosional seseorang.

Berkaitan dengan hasil wawancara terhadap beberapa orang responden di dapatkan informasi bahwa sebelumnya responden telah mendapatkan penyuluhan tentang perilaku mencuci tangan dari instansi kesehatan, sehingga dengan adanya paparan penyuluhan tersebut mempengaruhi sikap positif responden terhadap perilaku mencuci tangan.

Hal ini selaras dengan hasil penelitian Ratna Wati (2011) di Surakarta tentang Pengaruh Pemberian Penyuluhan PHBS tentang mencuci tangan terhadap Pengetahuan dan Sikap mencuci tangan pada siswa kelas V SDN Bulukantil menunjukkan hubungan yang signifikan dengan $p$ value pengetahuan $=0,000$.

Hasil penelitian menunjukkan $p$ value $=$ 0,005 artinya terdapat hubungan signifikan antara Sikap dengan penerapan Cuci Tangan Pakai Sabun dan Air mengalir di SDN II Kota Karang Bandar Lampung. Hal ini selaras dengan penelitian Maria Dian Indrayani Jahang (2013) di Manggarai Timur Flores, bahwa terdapat hubungan bermakna antara sikap dengan perilaku cuci tangan siswa-siswi SDK Rana Loba dengan $p$ value $=0,004$.

Strickland (dalam Hanurawan, 2010: 42) menjelaskan bahwa "sikap adalah predisposisi atau kecenderungan untuk memberikan respon secara kognitif, emosi, dan perilaku yang diarahkan pada suatu objek, pribadi, dan situasi khusus dalam cara-cara tertentu". Berbeda dengan penelitian zuraedah (2013) Di Lubuk Linggau menunjukkan tidak adanya hubungan yang signifikan antar sikap dengan perilaku cuci tangan pakai sabun pada kelas V SDIT AN NIDA.

Menurut Green dan Kreuter (2000), perilaku merupakan hasil dari seluruh pengalaman serta interaksi manusia dengan lingkungannya yang terwujud dalam bentuk pengetahuan, sikap dan tindakan. Perilaku dibentuk melalui suatu proses dan berlangsung dalam interaksi manusia dan lingkungan. Faktorfaktor yang mempengaruhi terbentuknya perilaku dibedakan menjadi dua, yaitu faktor intern dan ekstern. Faktor intern mencakup pengetahuan, kecerdasan, emosi, inovasi.

\section{Sarana Cuci Tangan Pakai Sabun}

Lawrence green mengatakan bahwa untuk terbentuknya perilaku seseorang dipengaruhi oleh tiga faktor dimana salah satunya adalah faktor pendorong (enabling factor). Faktor pendorong adalah faktor yang memungkinkan terjadinya perilaku. Faktor tersebut dapat berupa lingkungan fisik, sarana kesehatan, atau sumber-sumber khusus yang mendukung, dan keterjangkauan sumber dan fasilitas kesehatan. Sarana kesehatan dalam terbentuknya perilaku cuci tangan pakai sabun di sekolah tentunya adalah sarana yang harus disediakan dan dapat digunakan untuk pelaksanaan perilaku mencuci tangan pakai sabun secara benar, meliputi tempat mencuci tangan mengalir, sabun dan handuk untuk lap pengering tangan.

Hasil observasi peneliti di halaman sekolah terdapat dua buah kran air tetapi pemanfaatan lebih sering untuk menyiram bunga dan membersihkan atau mengepel ruangan kelas dan kantor. Kemudian di dalam kelas terdapat alat cuci tangan berupa dua buah waskom yang disediakan untuk cuci tangan guru, tetapi tidak setiap saat air waskom diganti dan diisi air. Beberapa responden mengatakan setelah buang air besar di sekolah tidak mencuci tangan dengan menggunakan sabun dikarenakan tidak disediakan di toilet siswa.

Hasil penelitian menunjukkan bahwa terdapat hubungan yang signifikan antara sarana cuci tangan dengan penerapan Cuci Tangan Pakai Sabun dan Air mengalir di SDN II Kota Karang Bandar Lampung dengan $p$ value $=0,039$ sehingga Ho ditolak. Menurut Lawrence Green (1980), dalam Notoamodjo (2003: 13) ada 3 faktor penyebab seseorang melakukan suatu perilaku kesehatan salah satunya adalah faktor Pemungkin (Enabling factors). Faktor ini 
mencakup ketersediaan sarana dan prasarana atau fasilitas kesehatan bagi masyarakat, misalnya air bersih, tempat pembuangan sampah, jamban dan sebagainya. Fasilitas ini pada hakikatnya mendukung atau memungkinkan terwujudnya perilaku kesehatan. Sarana yang dimaksud dalam penelitian ini adalah sarana cuci tangan.

Selaras dengan penelitian T Dwi Utomo (2013), menunjukkan hubungan signifikan dengan hasil $\mathrm{r}$ hitung $=0,925$ lebih besar dibanding dengan $r$ tabel yaitu 0,632 , akan tetapi hasil penelitian ini tidak selaras dengan penelitian Maria Dian Indrayani Jahang di SDK Rana Loba Manggarai Timur Flores tentang Faktor-faktor yang berhubungan dengan perilaku mencuci tangan di lingkungan SDK Rana Loba hasil $p$ value $0.373(>0.05)$, tidak ada hubungan yang bermakna antara ketersediaan fasilitas dengan perilaku cuci tangan pada siswa-siswi SDK Rana Loba, Kelurahan Rana Loba, Kabupaten Manggarai Timur. Disebutkan bahwa tidak adanya hubungan antara fasilitas dengan perilaku cuci tangan dapat disebabkan karena budaya dan kebiasaan yang sudah terbentuk dari rumah. Dapat juga disebabkan karena kurangnya peran guru sebagai role model di sekolah dalam penerapan cuci tangan di sekolah. Upaya lain yang dapat dilakukan adalah dengan memasukkan perilaku cuci tangan dalam tata tertib sekolah.

\section{Peran Guru terhadap Cuci Tangan Pakai Sabun dan Air Mengalir}

Hasil analisis menunjukkan distribusi siswa mendapat peran guru sebanyak 53 orang $(66,2 \%)$ sedangkan siswa yang tidak mendapat peran guru sebanyak 27 orang (33,8\%). Dengan demikian hasil penelitian menunjukkan prosentase terbanyak adalah pada siswa mendapat peran guru yaitu 53 orang $(66,2 \%)$.

Menurut Judge dan Bono ( 2001), teori perubahan perilaku self efficacy yang menekankan adanya contoh dalam diri seseorang sehingga perilaku seseorang dicontoh oleh masyarakat sekitar hingga menjadikan sebuah budaya masyarakat. Dalam penelitian ini pendekatan perubahan perilaku kesehatan siswa kususnya perilaku cuci tangan pakai sabun dapat terjadi dengan adanya peran guru yang memberikan contoh atau suri tauladan dengan membiasakan menerapkan perilaku cuci tangan di sekolah sehingga pada akhirnya akan menjadi perilaku yang membudaya di sekolah.

Penelitian Kushartanti menunjukkan pengaruh yang signifikan antara faktor peran guru dengan perilaku cuci tangan yaitu dengan $p$ value $=0,041$. Hasil penelitian menunjukkan $p$ value $=0,013$ sehingga menunjukkan hubungan yang signifikan antara Peran Guru dengan penerapan Cuci Tangan Pakai Sabun dan Air Mengalir di SDN II Kota Karang Bandar Lampung. Selaras dengan penelitian Kushartanti (2012) di SDN 3 Brebes tentang Beberapa Faktor yang Mempengaruhi Perilaku Cuci Tangan Pakai Sabun menunjukkan pengaruh yang signifikan antara faktor peran guru dengan perilaku cuci tangan yaitu dengan $p$ value $=0,041$

Penelitian lain yang selaras yaitu penelitian Fivi Melva Diana dkk (2013) tentang hubungan pengetahuan, sikap, peran guru dengan pelaksanaan program PHBS di SD Negeri 001 Tanjung Balai Karimun menunjukkan adanya hubungan yang signifikan antara peran gutu dan pelaksanaan program PHBS yaitu $p$ value $<0,05$

Menurut Lawrence Green (1980), dalam Notoamodjo (2003: 13) ada 3 faktor penyebab seseorang melakukan suatu perilaku kesehatan antara lain faktor penguat (Reinforcing factors) dalam penelitian ini faktor ini dapat berupa sikap, peran guru dan perilaku guru dalam penerapan cuci tangan pake sabun di sekolah yang oleh anak-anak sekolah (siswa) diyakini sebagai panutan sehingga siswa akan mencontoh sikap dan perilaku tersebut.

\section{Pengetahuan dan Perilaku Penerapan CTPS}

Hasil analisis menunjukkan distribusi siswa yang menerapkan perilaku Cuci Tangan Pakai Sabun sebanyak 57 orang $(71,2 \%)$ sedangkan siswa yang tidak menerapkan perilaku Cuci Tangan Pakai Sabun sebanyak 23 orang $(28,8 \%)$. Dengan demikian prosentase terbanyak adalah pada siswa yang menerapkan perilaku Cuci Tangan Pakai Sabun yaitu 57 orang $(71,2 \%)$.

Perilaku Mencuci Tangan Pakai Sabun adalah aktifitas mencuci tangan dengan mengikuti tahapan-tahapan mencuci tangan secara benar, dengan sabun atau cairan anti septik untuk membunuh kuman yang menempel pada tangan kemudian membilasnya dengan air mengalir. Sedangkan tujuan mencuci tangan dengan sabun dan air mengalir untuk membersihkan kuman penyakit baik bakteri ataupun virus yang menempel pada telapak tangan, punggung tangan dan sela sela jari tangan, sehingga terhindar dari menjadi agen sumber penyebaran penyakit.

Fajar Ardi Desiyanto (2013), menunjukkan perbedaan jumlah angka kuman yang 
signifikan pada aktifitas mencuci tangan dengan menggunakan sabun dengan $p$ value 0,0008 .

Berdasarkan Hasil uji statistic chi square didapatkan hasil $p$ value $=0,074$ sehingga dapat disimpulkan bahwa tidak ada hubungan yang signifikan antara pengetahuan dengan perilaku cuci tangan. Penelitian ini selaras dengan penelitian Fajar, Nur Alam dan Misniarti (2011) yang menunjukkan tidak ada hubungan yang signifikan antara pengetahuan dan perilaku mencuci tangan pakai sabun.

Secara teori Green mengatakan bahwa ada beberapa hal yang mempengaruhinya yaitu kepercayaan, kebiasaan, nilai-nilai, faktor sosiodemografi, lingkungan fisik, dan sarana (Maulana, 2009).

Hasil observasi dan wawancara dengan beberapa responden, pengetahuan responden dalam perilaku cuci tangan sudah baik, hal ini ditunjukkan prosentase yang lebih besar pada anak yang berpengetahuan baik yaitu 78,8\% Akan tetapi belum melaksanakan perilaku mencuci tangan dengan baik dan benar. Kondisi tersebut dikarenakan sebagian responden mengatakan tidak ada sarana mencuci tangan di sekolah, seperti sabun, lap tangan untuk pengering.

Hasil Analisis diatas tidak selaras dengan penelitian Zuraedah (2013) menunjukkan bahwa ada hubungan antara pengetahuan dengan perilaku mencuci tangan dengan benar di Lubuk Linggau dengan $p$ value $=0,029$.

Pengetahuan adalah sesuatu yang dikemukakan seseorang yang merupakan hasil dari tahu. Hal ini dapat terjadi setelah individu

\section{DAFTAR PUSTAKA}

Dinas Kesehatan Provinsi Lampung, 2013. Profil Kesehatan. Dinas Kesehatan Provinsi Lampung.

Dinas Kesehatan Provinsi Lampung. 2012. Profil Kesehatan. Dinas Kesehatan Provinsi Lampung.

Fajar Ardi Desiyanto, efektivitas mencuci tangan menggunakan cairan pembersih tangan antiseptik (hand sanitizer) terhadap jumlah angka kuman. Jurnal Kesehatan Masyarakat (Journal of Public Health) vol. 7 no.2 September 2013.

Green, L.W. Kreuter, M.W, 2000. Health Promotion Planning an Educational and Environmental Approch; Second Edition, Mayfield Publishing Company. Houston..

Hanurawan, Fattah. 2010. Psikologi Sosial. Bandung: Remaja Rosdakarya. melakukan penginderaan terhadap suatu objek tertentu. Penginderaan terjadi melalui pancaindera manusia, yakni indera penglihatan, pendengaran,penciuman, rasa dan raba dimana sebagian pendengaran manusia diperoleh dengan mata dan telinga. Pengetahuan merupakan domain yang sangat penting dalam membentuk tindakan seseorang (Notoadmodjo, 2003:121).

\section{SIMPULAN}

1. Responden dengan Pengetahuan baik prosentasenya lebih banyak (65\%)

2. Responden dengan sikap mendukung Perilaku Cuci Tangan prosentase lebih banyak $68,8 \%$

3. Responden dengan pendapat tersedia sarana cuci tangan prosentase lebih banyak (55\%)

4. Responden yang berpendapat peran guru menunjukkan prosentase $(66,2 \%)$

5. Responden yang menerapkan Perilaku Cuci Tangan pakai Sabun lebih banyak ( 71,2 \%).

6. Tidak ada hubungan signifikan antara pengetahuan responden dengan perilaku cuci tangan di SD II Kota Karang.

7. Ada hubungan signifikan antara sikap responden dengan perilaku cuci tangan pakai sabun dan air mengalir.

8. Ada hubungan signifikan antara sarana cuci tangan dengan perilaku cuci tangan pakai sabun dan air mengalir.

9. Ada hubungan yang signifikan antara peran guru dengan perilaku cuci tangan pakai sabun dan air mengalir.

Hastono Sutanto dan Sabri Lubis. 2011. Statistik Kesehatan. Jakarta: Rajawali Pers.

Judge dan Bono. (2000). Five-Factor Model of Personality and Transformational Leadership. Journal of Applied Psychology, Vol. 85 No.5: p.751- 765.

Kementerian Kesehatan. 2007. Riset Kesehatan Dasar. Kementerian Kesehatan Republik Indonesia. Jakarta.

Kementerian Kesehatan. 2013. Riset Kesehatan Dasar. Kementerian Kesehatan Republik Indonesia. Jakarta

Maria Dian Indrayani dkk. Faktor-faktor yang berhbungan dengan perilaku cucintangan di lingkungan sdk rana loba manggarai Timur Flores NTT. ejournal.stiksintcarolus.ac.id 
Monica dkk. Faktor-faktor yang berhubungan dengan perilaku mencuci tangan pada anak sekolah dasar negeri 03 kertajaya padalaran. ejournal.stikesborromeus.ac.id

Notoadmodjo, Soekijo 2003 Pendidikan dan Perilaku Kesehatan. Jakarta: Rineka Cipta.

Notoadmodjo, Soekidjo. 2005. Metodologi Penelitian Kesehatan. Jakarta: Rineka Cipta.

Notoadmodjo, Soekidjo. 2010. Metodologi Penelitian Kesehatan. Jakarta: Rineka Cipta.

Pusat Promosi Kesehatan Depkes RI. 2011. Interaksi Suplemen PHBS di Sekolah. Jakarta.

Pusat Promosi Kesehatan, Departemen Kesehatan Republik Indonesia. 2008 Perilaku Hidup bersih dan sehat di sekolah.

Pusat Promosi Kesehatan Departemen Kesehatan Republik Indonesia. 2011. Perilaku Hidup Bersih Sehat.

Pusat Promosi Kesehatan Departemen Kesehatan Republik Indonesia. 2010. Perilaku Hidup bersih dan sehat di sekolah.

Quintero, Catalina, Freeman. et all. 2009. Hand Washing Among School Children In Bogota Columbia. American Journal Of Public Health. 94-101. 2015. http://www.search.proques.com
Ratna Wati, 2011, Pengaruh Pemberian Penyuluhan PHBS tentang mencuci tangan terhadap Pengetahuan dan Sikap mencuci tangan siswa kelas $V$ SDN Bulukantil. http://eprints.uns.ac.id/6069

Sugiyono. 2010. Statistik Untuk Penelitian. Bandung: Alfabeta.

Suharsini Arikunto. 2010. Prosedur Penelitian. Jakarta: Rineka Cipta.

Suryadi. 2012. Faktor-fakor yang berhubungan dengan Perilaku Hidup Bersih dan Sehat pada Murid SD Negeri 1 Kota Subulussalam. Jurnal Nasional Kesehatan Masyarakat vol 2.

$\mathrm{T}$ Dwi, Utomo (2013) hubungan antara ketersediaan sarana dan prasarana usaha kesehatan sekolah dengan perilaku hidup sehat siswa kelas vi sd negeri mungkung kecamatan kalikajar kabupaten wonosobo tahun 2013. http:// eprints.uny.ac.id/1479

Vivas dkk. 2010. Knowledge, Attitudes, and Practices (KAP) of Hygiene among School Children in Angolela, Ethiopia.

Zuraidah 2013, Hubungan Pengetahuan dan Sikap dengan Perilaku Mencuci Tangan dengan benar pada siswa kelas VI SDIT AN NIDA'Kota Lubuk Linggau. ejournal.Stikesborromeus.ac.id/file diakses tgl 22 Desember 2015. 